\title{
A new genus of "miacid" carnivoran from the earliest Eocene of Europe and North America
}

Thierry Smith and Richard Smith

Acta Palaeontologica Polonica 55 (4), 2010: 761-764 doi: http://dx.doi.org/10.4202/app.2009.0125

"Miacid" carnivorans comprise one of the modern mammal groups appearing around the Palaeocene-Eocene Thermal Maximum (PETM) in the Northern Hemisphere. Here we describe a new very small "miacid" carnivoran from the earliest Eocene of Dormaal, Belgium, that shares a particular dental morphology with the species "Miacis" winkleri and "Miacis" rosei from the early Eocene of North America. The three species present very gracile and sharp teeth, and are hereby placed in the new genus Gracilocyon. Comparative dental analysis of Gracilocyon with other early "miacids" contributes to better resolve the polarity of dental characters and indicates that this genus is one of the most primitive members of the family. Diversity of early modern carnivorans is greater than previously considered and early "miacids" seem to have dispersed into North America from two different geographic origins.

Thierry Smith [thierry.smith@naturalsciences.be] and Richard Smith [richardsmithpal@hotmail.com], Royal Belgian Institute of Natural Sciences, Department of Paleontology, Rue Vautier 29, B-1000 Brussels, Belgium.

This is an open-access article distributed under the terms of the Creative Commons Attribution License (for details please see creativecommons.org), which permits unrestricted use, distribution, and reproduction in any medium, provided the original author and source are credited. 